\title{
Collective control of the timing and type of comb construction by honey bees (Apis mellifera)
}

\author{
Stephen C. PRATT* \\ Department of Ecology and Evolutionary Biology, Princeton University, Princeton NJ 08544, USA
}

(Received 1st August 2003; revised 5 November 2003; accepted 2 December 2003)

\begin{abstract}
This review considers how a honey bee colony optimally controls the timing and type of new comb construction. Optimal timing requires bees to balance the energy costs of construction with the opportunity costs of lacking storage space during nectar flows. They do so by conditioning the start of building on (1) the attainment of a fullness threshold, and (2) the availability of nectar. A dynamic optimization model has suggested that this rule is slightly suboptimal, but may compensate for this by its simplicity and generality. The emergence of this collective strategy from the decisions of individual bees is poorly understood, but recent experiments have cast doubt on the long-standing idea that building is triggered by increased distension of the crops of nest bees. Bees also regulate the relative amounts of drone and worker comb in their nests, with important consequences for their sex investment strategy. Regulation depends on the inhibitory effect of drone comb on further drone comb construction, mediated through a decentralized process requiring that workers have direct contact with the comb. Contact by the queen is not required, nor is the presence of drone brood, although the latter may enhance the strength of inhibition.
\end{abstract}

\section{honey bee / comb / drone / decentralized control / life history / self-organization}

\section{INTRODUCTION}

Like the organisms to which they are often compared, honey bee (Apis mellifera L.) colonies undergo an orderly process of growth and development. Just as a developing organism must allocate limited resources among organs serving different functions, a developing colony must balance its investment in various worker castes, nest structures, and food stores (Perrin and Sibly, 1993; Zera and Harshman, 2001). For organisms, we expect an allocation pattern that maximizes individual fitness, but for colonies, natural selection should instead enhance the growth and reproduction of the colony as a whole, because individual members achieve fitness principally through colonial success. The optimal allocation is rarely obvious, as the fitness benefit of each function changes with colony age, size, and environ- ment, prescribing a dynamic and contextdependent pattern. The identification of these optimal patterns stands as a central problem in the developmental biology of insect societies.

This ultimate question opens in turn the proximate one of how a given allocation pattern at the colony-level emerges from the behavior of individual workers. These mechanisms are also rarely obvious, as the workers must generate a pattern attuned to global colony and environmental conditions, even though they typically have direct access only to very limited local information. Correct allocation further requires concerted action by thousands of these poorly-informed bees. Because the colony lacks a central controller, coordination relies on subtle, distributed mechanisms combining individual decision rules with specialized signals and informative local cues. Linking worker to colony behavior

\footnotetext{
*Corresponding author: spratt@ princeton.edu
} 
requires identification of these individual components, as well as hypotheses of how they interact to create the colony-level pattern.

This review considers these ultimate and proximate questions in the context of a particularly important "organ": the colony's complement of wax combs. Comb provides both cradles for developing young, and larders for the food stores needed to survive fallow periods. Its construction has attracted extensive research effort (Hepburn, 1986; Hepburn, 1998), much of it directed at how bees create orderly arrays of regular hexagonal cells (Huber, 1814; Lau, 1959; Darchen, 1968; Belic et al., 1986; Hepburn, 1986; Hepburn and Whiffler, 1991; Pratt, 2000). This review will focus instead on two life history questions about the colony's control of comb building. First, how do bees set the timing of construction to balance the energetic costs of building with the opportunity costs of lacking sufficient comb to exploit rich but brief nectar flows? Second, how do colonies regulate the type of comb built to maintain the appropriate amount of the two principal kinds of cell: large ones for rearing drones and small ones for rearing workers? Although these questions apply to honey bees of all climates, this review is largely confined to those of the temperate zone, where seasonal extremes render the timing challenge particularly acute, and where the bulk of research on the control of comb construction has been carried out. It should therefore be kept in mind that tropical honey bee races, facing very different climatic conditions, flowering plant phenologies, and life history challenges (Hepburn and Radloff, 1998), may adopt quite different strategies from those reported here.

\section{TIMING OF COMB CONSTRUCTION}

\subsection{Construction timing dilemma}

Once a swarm settles into an empty nest cavity, it immediately faces the challenge of building comb. When fully developed, the nest will typically contain over $1 \mathrm{~m}^{2}$ of comb (Seeley and Morse, 1976), most of it built during the colony's first year (Lee and Winston, 1985). Comb is vital to the colony's future, both for brood-rearing to replenish and expand the workforce, and for storage of the vast hoard of honey the colony must collect over its first spring and summer. Large honey stores allow the bees to rear brood even during the coldest part of winter, creating foraging forces to exploit early spring nectar flows. This rapid start in turn ensures ample fuel for the generation of reproductive swarms and the accumulation of the next winter's hoard (Seeley and Visscher, 1985).

Important though the comb is to this effort, its construction poses a major resource allocation dilemma. On the one hand, the colony will benefit from building plenty of comb early on, so that it can efficiently exploit brief and temporally unpredictable nectar flows. Not only does the comb supply limit honey stores, but a shortage of empty comb may reduce foraging efficiency, as nest bees become mired in lengthy searches for empty cells in which to place incoming nectar (Seeley, 1995). On the other hand, construction also saps the colony's energy supplies, through the costly production of wax from the sugars in collected honey (Hepburn, 1986), and through thermoregulation of the building site by the surrounding festoon of bees (Hepburn et al., 1984). The total cost of building $1 \mathrm{~kg}$ of comb has been conservatively estimated at $6.25 \mathrm{~kg}$ of honey (Weiss, 1965). Thus, the $1.2 \mathrm{~kg}$ of comb in a fully developed colony consumes an impressive $7.5 \mathrm{~kg}$ of the $60 \mathrm{~kg}$ of honey consumed each year by a typical temperate-zone colony (Seeley, 1985). Once an investment in comb is made, the colony cannot later redirect it to other needs, as bees do not eat wax. Thus building too much comb too early will deplete honey stores and so threaten overwinter survival. Steep mortality rates during the colony's first winter $-71 \%$ in one New York State population (Seeley, 1978) - underscore the importance of striking the right balance between the energy costs of construction and the opportunity costs of missed nectar flows.

\subsection{Condition-dependent construction}

The bees solve their dilemma by making new construction contingent on colony and environmental state. After an initial burst of construction to initiate brood-rearing and food storage, a newly settled swarm does not build 
its comb all at once, but instead adds it in pulses throughout the spring and summer (Hepburn, 1986; Pratt, 1999). What governs the timing of these pulses? Many conditions must be met before a colony will build. For example, bees are reluctant to initiate construction except in darkness (Morse, 1965), and building is reduced or eliminated in the absence of a queen (Darchen, 1968; Hepburn et al., 1984; Free, 1987; Whiffler and Hepburn, 1991; Ledoux et al., 2001). Likewise, inadequate pollen nutrition after worker eclosion interferes with normal wax gland development and so inhibits construction (Goetze and Bessling, 1959; Freudenstein, 1960). While these factors are relatively static and thus unlikely to account for frequent sharp changes in activity over a foraging season, two other factors vary widely over this time scale: (1) the colony's daily nectar intake and (2) the amount of empty comb available for storage. The importance of nectar intake has long been noted by apiculturists, particularly in triggering the start of comb-building each spring (Koch, 1961; Hepburn, 1986). Likewise, producers of comb honey well appreciate the link between comb fullness and vigorous construction. Both nectar flow and comb fullness were more firmly linked to construction by Pratt (1999) who established a swarm in an initially combless observation hive and tracked it through its first spring and summer. Pulses of building were found to be significantly correlated both with periods of high comb fullness and with peaks of weight gain, a reliable indicator of nectar intake (McLellan, 1967) (Fig. 1).

These correlations suggest that bees condition building on the satisfaction of two requirements: adequate nectar collection in the field, and the filling of their comb above a threshold level. Because incoming nectar tends to fill available comb, these two factors can be highly correlated with one another (Pratt, 1999), hence observational data alone cannot determine whether both are important, or only one. Controlled experiments have demonstrated that, in fact, the start of building requires both comb fullness and nectar intake (Kelley, 1991; Seeley, 1995; Pratt, 1999). In particular, when a colony was provided with space in which to build new comb and fed a concentrated sucrose solution, it refrained
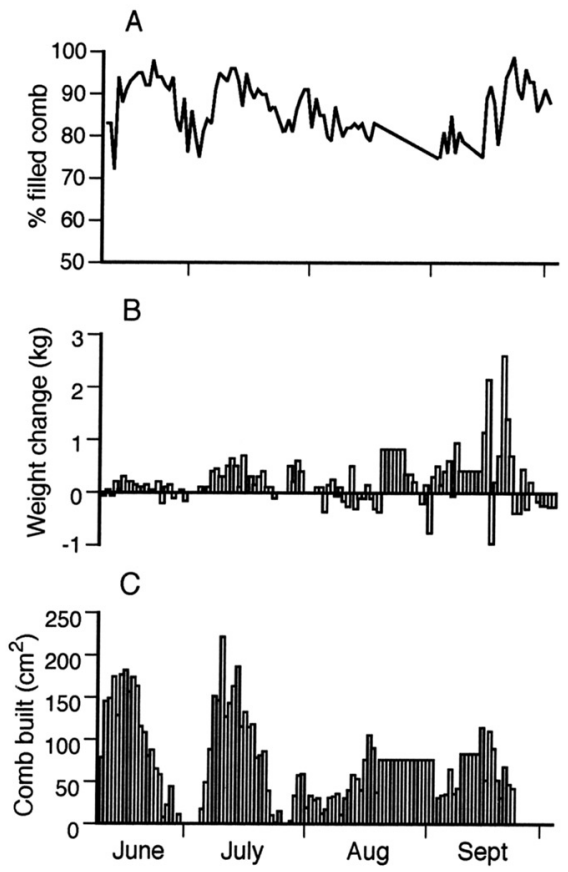

Figure 1. Daily measurements of comb fullness, nectar intake, and new comb construction in an observation colony over the course of a nectarcollecting season. (A) Percentage of comb area comprised of cells containing food or brood for each day. (B) The colony's daily weight change, an estimate of its nectar intake. (C) The area of new comb constructed each day. Significant positive correlations were found between daily nectar intake and comb construction on the following day $(\mathrm{r}=$ $0.35, P<0.05)$, between comb fullness on each day and the amount of comb built on that day $(\mathrm{r}=0.27$, $P<0.05$ ), and between comb fullness on each day and nectar intake on that day $(\mathrm{r}=0.40, P<0.05)$. Adapted from Pratt (1999).

from building as long as a low level of comb fullness was maintained by regular replacement of the filling storage comb with empty comb (Pratt, 1999) (Fig. 2). Only when the bees were allowed to fill their comb did they begin to build. A companion experiment showed that fullness is not, by itself, a sufficient condition. A colony failed to start building as long as it was deprived of nectar intake, even though it was maintained at a high level of fullness by daily replacement of its emptying storage comb with filled comb (Pratt, 1999) (Fig. 3).

While both nectar intake and comb fullness are necessary for building to start, nectar 


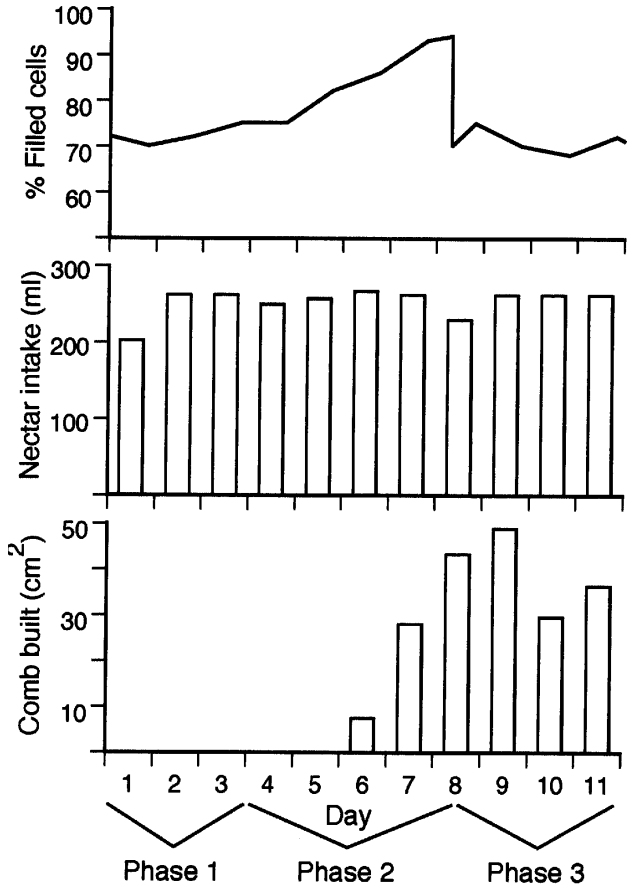

Figure 2. Results of an experiment testing the role of comb fullness in a colony's decision to start building new comb. In phase 1 , the colony experienced a heavy intake of sucrose solution but was maintained at a low level of comb fullness. In phase 2 , sucrose intake continued, but the bees were allowed to fill up their comb with honey. In phase 3 , the colony was returned to the conditions of phase 1 . The bees built no new comb in phase 1 , commencing construction only in phase 2 after the level of comb fullness had markedly increased. The bees did not, however, cease construction when the level of comb fullness was lowered in phase 3. Adapted from Pratt (1999).

intake alone can maintain construction once it has begun. This was shown in the later parts of the experiments described above. When the storage comb of a building colony was experimentally replaced with empty comb, reducing its fullness to levels too low to trigger the start of construction, the bees nonetheless continued to build (Fig. 2). In contrast, a building colony that was deprived of nectar intake ceased construction after two days, even though its combs remained full (Fig. 3). Thus the length of a building bout is regulated somewhat differently from its initiation. It should be noted, however, that sharp drops in comb fullness during a nectar flow are

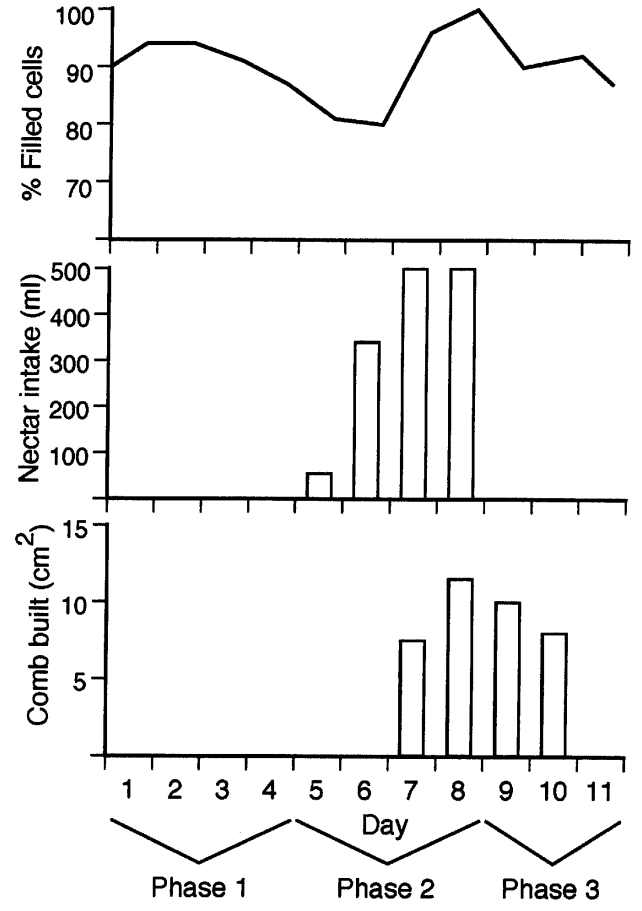

Figure 3. Results of an experiment testing the role of nectar intake in a colony's decision to start building new comb. In phase 1, the colony experienced a high level of comb fullness, but received no nectar whatsoever. In phase 2 , the bees were fed a $2.5 \mathrm{M}$ sucrose solution while their level of comb fullness remained high. In phase 3, the colony was returned to the conditions of phase 1 . The bees built no new comb in phase 1, commencing construction only in phase 2 after experiencing 2 days of nectar intake. The bees ceased construction 2 days after nectar intake was cut off in phase 3. Adapted from Pratt (1999).

unlikely events in the normal life of a colony, as nectar intake will tend to fill available cells with honey. Thus, continued nectar intake alone should generally be a good indicator to a building colony of the continued need for more comb.

\subsection{Optimal condition-dependent strategies}

The strategy described above makes intuitive sense as a means to balance the benefits and costs of new construction. Attending to the amount of empty comb in the nest should trigger construction in time to prevent 
dangerous inefficiencies in nectar collection as storage space grows scarce. At the same time, this rule can prevent the bees from wasting energy on construction when plenty of storage capacity is already available. Attending to nectar intake should further discourage waste by conditioning building on the substance that both provides the fuel for new comb and makes the single greatest demand for its construction, with over half of the comb in a mature nest used for storing honey (Seeley and Morse, 1976).

Aside from it intuitive appeal, is this strategy really the best one available to a colony that has information about both comb fullness and nectar intake? This question has been addressed by Pratt (1999) through the application of stochastic dynamic programming, an optimization technique well-suited to studying the fitness effects of state-dependent behavioral decisions over time (Mangel and Clark, 1988). The goal of the model was to determine the optimal building behavior of a colony in its first foraging season, as a function of the day of the season and of three state variables: the quantity of nectar available to be collected in the field, the amount of comb already present in the nest, and the amount of nectar already stored in the comb. To explore the effects of the foraging environment on optimal building policy, the model was run with several different values for the average richness and temporal variability of nectar flows.

The model's principal conclusion was that bees pursuing an optimal policy should build new comb only on days when the fullness of comb already present exceeds a threshold. This conclusion applied whether food sources were rich or poor and whether nectar flows were clumped or dispersed. The exact size of the fullness threshold did vary with foraging conditions, but it was typically rather low, with building the optimal choice even when sufficient storage for several kilograms of honey was already available. Thus, the model predicted a fairly aggressive building policy designed principally to avoid the dangers of insufficient storage capacity. Both the existence of a threshold and its low level are consistent with the actual effect of comb fullness described above.

The predicted influence of nectar conditions was more complex, and less similar to the experimental results. In general, the model concluded that bees should demand a higher fullness threshold for building on days when nectar is not available in the field. The difference in threshold between good and bad nectar days, however, depended on average foraging conditions, growing quite small with declining richness and with more even dispersal of nectar flows in time. Only for rich and strongly clumped nectar flows did the predicted policy approximate the experimental observations: that is, the bees should build with a very low threshold when nectar is available and a very high one when it is not.

One interpretation of these results is that bees follow a policy adapted to conditions of very rich and clumped food sources. Clearly, bees often depend on this kind of resource. The colony depicted in Figure 1 earned 50\% of its $55 \mathrm{~kg}$ gross weight gain on only 13 days of the 150-day foraging season (Pratt, 1999). Nonetheless, honey bees have evolved over a very broad geographical and ecological range, and it might be expected that their building strategy has been shaped by selection to function well in a diversity of foraging environments. An analysis of suboptimal building strategies has suggested that the bees' policy may in fact serve as a simple but general solution to the timing problem (Pratt, 1999). Using a modification of the dynamic programming algorithm, the fitness expected from following each of several alternative strategies was calculated and compared to the maximum fitness gained via the optimal strategy. The results showed that strategies failing to build when nectar is available or building too much when nectar is absent pay a large fitness cost, but those straying in the other direction, building too readily during nectar flows or too little during nectar dearths, are little different from the optimal strategy. Significantly, the strategy actually used by bees - building with a low threshold during nectar flows and refraining entirely from building in the absence of nectar intake - earns only slightly lower expected fitness than the optimal strategy, regardless of nectar conditions. This suggests that bees are using a slightly suboptimal but robust strategy, effective over a wide range of foraging conditions. They pay only a small fitness cost for the information processing advantages of a simple rule of thumb, rather 
than precisely tuning fullness thresholds to particular conditions.

\subsection{Individual behavioral mechanisms}

The strategy described above somehow emerges from the individual decisions of thousands of worker bees. This emergence is puzzling, as the strategy depends on two largescale features of environmental and colony state, but each bee likely has direct access only to limited local information about her surroundings. Moreover, nectar conditions in the field are directly perceived only by foragers, and these older bees do not normally participate in construction (Rösch, 1927; Seeley, 1982). The middle-aged builders are betterplaced to monitor comb fullness, but it is not obvious how they can detect this global feature of a comb complement that can exceed $1 \mathrm{~m}^{2}$ in area.

The emergence of global coordination from the interactions of locally informed individuals is a fundamental property of insect social organization (Camazine, 2001). Coordination commonly relies on attendance by workers to local cues correlated with relevant global properties (Detrain and Deneubourg, 2002). Ribbands (1953) long ago suggested that the key to the bees' comb-building strategy lies in such a cue, namely the prolonged filling of the crops of nest bees with nectar. Bees in the 10 to 20 day age range most responsible for comb-building are also disproportionately active in the task of unloading nectar from incoming foragers and storing it in comb cells (Rösch, 1927; Seeley, 1982). This occupation puts them in a good position to monitor both nectar intake and comb state, as they regularly encounter both comb and foragers. In particular, when nectar intake coincides with dwindling storage capacity, receiver bees will experience prolonged filling of their crops, as a result of delays in finding empty cells in which to deposit recently received nectar. Ribbands did not specify the mechanism by which cropfilling might release construction, but one reasonable scenario posits detection of prolonged crop distension by stretch receptors in the abdominal wall, in turn triggering wax secretion and comb-building.

Attractive as this idea sounds, experimental investigation to date has not supported it. One problem is that nectar receivers appear not to compose a large proportion of the bees in building festoons (Pratt, 1998a). When several hundred nectar receivers were paint-marked, and their colony was then induced to start building, disproportionately few of the marked bees turned up in the building festoons. In fact, marked bees consistently made up less than $5 \%$ of the builders, even though an estimated 30 to $40 \%$ of receivers had been marked. Indeed, marked bees made up far less of the building population than would be expected if builders were randomly chosen from the total colony population, of which 6 to $16 \%$ had been marked. Thus, far from providing a pool of potential builders, nectar receivers appear less likely than other bees to join building festoons.

A limited role for nectar receivers in building is perhaps unsurprising. Because colonies build only during nectar flows, reliance on receivers as builders could reduce nectar intake by diverting storage effort precisely when it is most needed. To avoid this cost, colonies could instead reallocate labor from other tasks, or call up underused reserves. The latter possibility is suggested by the results of Kolmes (1985), who found that colonies deprived of comb managed to increase building effort without showing any reduction in the time spent in other tasks, compared to control colonies given ample comb. Bees instead spent less time grooming and standing still, suggesting that the colony responded by activating reserve effort rather than by shifting effort from other tasks. Likewise, when Ferguson and Winston (1988) induced varying construction effort among experimental colonies, by providing them with different amounts of fully drawn comb, they found that workers started to forage at an earlier age in those colonies given the least amount of comb. Moreover, they found no effect of comb treatment on development of the acinus hypopharyngeal glands, whose peak size in young bees is associated with its role in secreting brood food. These results are consistent with the simultaneous enhancement of building and foraging by recruitment of a reserve labor force, rather than by diverting effort from brood care.

Even if nectar receivers do not build, the crop distention hypothesis might be rescued if 
other bees also experience enlarged crops as a reliable indicator that building conditions have been met. In fact, receivers regurgitate much of their load to other house bees, who in turn pass it on themselves or store it in empty comb cells (Seeley, 1989). These "downstream" bees might also experience crop distension as a side effect of the coincidence of nectar intake and comb fullness, and could respond by building comb. Studies performed to date, however, do not support such a role for crop engorgement. Hepburn and Magnuson (1988) found no effect of the amount of empty comb available for storage on the mass of nectar in the crops of house bees or on the mass of wax borne on their abdomens, nor did they find an effect of nectar intake on crop mass. They did find a significant correlation between crop mass and wax secretion, but their data could not distinguish whether engorgement stimulated wax secretion or whether both factors were instead independent consequences of the decision to begin building (that is, bees that have decided to build might gorge on nectar to provide fuel for wax secretion). Pratt (1998a) attempted a more direct test of the causal relationship between engorgement and building behavior, by tracking the crop size of potential builders as a colony experienced the onset of building conditions. A colony that was not building was induced to start by heavy feedings with sucrose solution. As it moved from idleness to vigorous building, daily samples of marked 10-day old bees were taken and their crops removed and weighed. No trend was detected toward increasing crop size, suggesting that crop distension is not necessary to trigger a building bout.

Cues such as crop distension, that arise only with congestion of the colony's nectar storage pipeline, may be too insensitive to account for the bees' tendency to add new comb even at quite low levels of fullness. Small experimental colonies start to build when sufficient empty comb is still available for several kilograms of honey (Pratt, 1999). Instead of waiting for congestion as a singular cue of the coincidence of nectar intake and threshold comb fullness, potential builders may independently track the two conditions, continuously updating their estimate of each through their encounters with nestmates and cells. That is, their rate of encounter with nestmates offer- ing to regurgitate fresh nectar could inform them of foraging conditions, and their relative rate of encounter with empty and full cells could tell them about comb fullness. The behavior of unemployed builders gives indirect support for this scenario. When bees in a building festoon were marked and then observed a day later, after building had been curtailed by reduction of the colony's nectar intake, they engaged at a low but steady rate in food exchange and in brief cell inspections (Pratt, 1998a). These interactions, although comprising only about $3 \%$ of their total time budget, could provide crucial information about both comb conditions and nectar intake.

\section{CONTROL OF COMB TYPE}

In addition to deciding when to build, colonies must choose the type of comb to build: drone cells or worker cells. This decision has important implications for colony life history. Although most cells of both types are used for food storage, the numbers of each type partly determine worker and male production, by placing upper limits on how many of each caste can be reared. Indeed, Page et al. (1993) found a positive correlation between drone comb area and drone brood area. The ratio of workers to males affects both the colony's relative investment in growth vs. reproduction, and its sex allocation, because the workers left behind with a daughter queen at swarming constitute a major part of investment in female reproduction (Page and Metcalf, 1984).

\subsection{Effects of age, size, and queen status}

Given these effects, it is not surprising that the type of comb built by a colony changes with age and size. Swarms newly settled in their nests make only worker cells for the first several weeks of construction, and very small colonies tend to build less drone comb than larger colonies (Free, 1967; Taber and Owens, 1970; Lee and Winston, 1985). This seems to reflect a strategy of early concentration on the colony's "somatic" organs - the workers that will acquire energy for further growth before investing in reproductive effort.

A colony's choice of comb type also depends strongly on its queen status. As noted 
above, queenless colonies build much less comb than queenright colonies, but the comb they do build is heavily weighted toward drone cells. Ledoux et al. (2001) found that queenless artificial swarms built comb consisting largely of drone-sized or intermediate cells. The queen's influence appeared to be mediated by mandibular pheromone, with dispensers of synthetic pheromone yielding cell proportions similar to those of queenright swarms. The building strategy of these hopelessly queenless swarms allows them to achieve some fitness through drone production in their final weeks of life. These results were obtained with bees of European origin, but Neumann et al. (2000) found similar results for A. mellifera scutellata in South Africa, where colonies whose queen, brood, and comb had been removed subsequently built only drone cells. Interestingly, A. m. capensis colonies responded to the same manipulation by building largely or exclusively worker cells. This difference corresponds to the distinct reproductive potentials of the two subspecies. The arrhenotokous workers of $A$. $m$. scutellata can produce only males, while the thelytokous A. m. capensis workers can become pseudoqueens and lay female eggs.

\subsection{Regulation of drone comb construction}

Once a queenright colony grows large enough to build both drone and worker comb, it closely regulates the proportions of each in its nest. Mature feral nests in upstate New York, for example, were found to contain a mean $17 \%$ drone comb by area, with a range of $10.0 \%$ to $24.2 \%$ (Seeley and Morse, 1976). Experimental studies of hived colonies building their comb from scratch found greater variation, with drone comb proportions ranging from $0 \%$ to $34.7 \%$ (Lee and Winston, 1985) and $0 \%$ to $27 \%$ (Page et al., 1993), perhaps reflecting the colonies' relative youth and small size. In all cases, however, drone comb generally made up less than one-quarter of total comb area. Other experiments show that these proportions result from active regulation of construction effort: colonies provided exclusively with worker comb build significantly more drone comb than colonies amply supplied with drone comb (Free, 1967; Free and Williams, 1975; Pratt, 1998b).
The behavioral mechanisms underlying this regulatory ability present a puzzle at least as great as that of construction timing. Not only must each bee respond to a global feature of the colony's entire comb complement when deciding what kind of cell to build, but she must also coordinate her choice with thousands of fellow builders. Comb construction is a highly distributed activity, with workers moving frequently along the growing comb edge, adding or shaping wax briefly at one site before moving to another. Thus, each cell grows from the labors of many bees, all of whom must agree on what they are building if construction is to remain coherent.

The bees' solution to this challenge remains largely unknown, but some of the key information pathways that govern their decision have been identified. A series of experiments has examined how well colonies regulate their construction when deprived of potential cues about their current comb type (Pratt, 1998b) (Fig. 4). The results show, first, that bees require direct contact with drone comb in order for its presence to inhibit the construction of further drone comb. Second, the queen plays no role in this contact-mediated regulation. Drone comb shows its normal inhibitory effect even when a queen excluder allows only the workers to contact it. Third, inhibition arises from the drone comb itself, even in the absence of drone brood. Empty drone comb that has never been used to rear brood reduces new drone comb construction relative to colonies with only worker comb. Brood does, however, enhance this inhibition, as shown by the still more worker-biased comb built by colonies supplied with brood-filled drone comb (Pratt, 1998b).

These findings reveal the highly decentralized nature of drone comb regulation. In particular, they exclude two appealingly simple but quite centralized alternative mechanisms. First, the amount of drone comb in the nest might be directly communicated to each builder in the form of a volatile chemical signal, perhaps originating in a distinctive pheromone worked into the drone comb as it is constructed (Free, 1987). If the concentration of this signal varied with the amount of drone comb in the nest, then each builder would have 
A

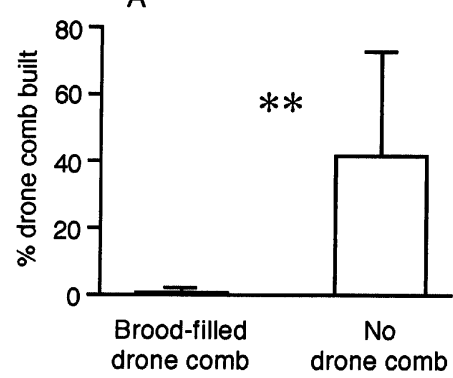

C

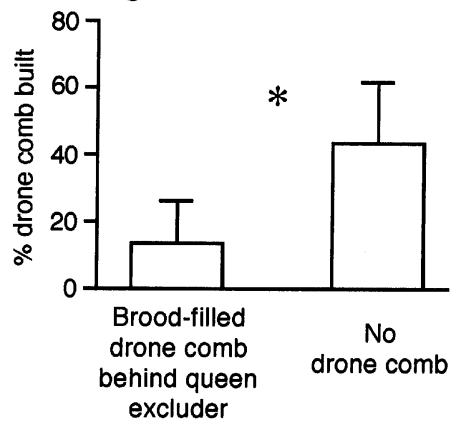

B

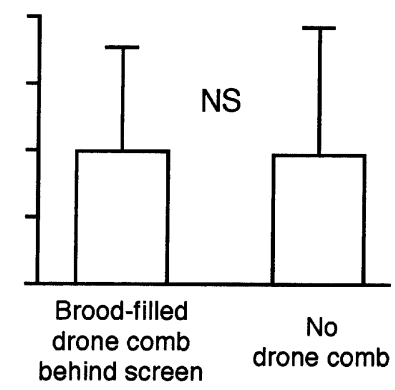

D

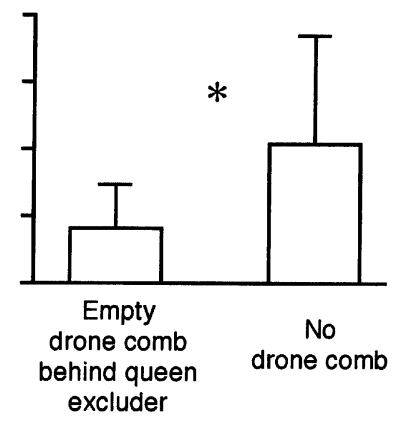

Figure 4. Results of four experiments comparing the composition of new comb built by 12 colonies under two initial comb supplies: (1) no drone comb, and (2) ample drone comb (25\% of total comb area). Access to potential cues of comb type was altered in each experiment. (A) When given free access to brood-filled drone comb, colonies built significantly less drone comb than when initially provided only with worker comb. (B) When a wire mesh screen denied the bees tactile contact with brood-filled drone comb, the composition of their new construction did not significantly differ from that built in the absence of any drone comb. (C) When a queen excluder kept the queen, but not the workers, from direct contact with brood-filled drone comb, the bees built significantly less drone comb than in the pure worker comb treatment. (D) When initially supplied with empty drone comb that had never been used for drone rearing, colonies built significantly less drone comb than when initially supplied only with worker comb. All comparisons were made via one-tailed paired t-tests on arcsine square-root transformed data (NS: not significant, $*: P<0.05$, **: $P<0.01)$. Adapted from Pratt (1998b).

ready access to a common source of information about drone comb need, ensuring a uniform decision by all builders. This appears not to be the case, as workers require direct contact with comb to respond to its presence. Second, drone comb regulation might rely on the queen acting as a central information processor. She occupies an ideal position from which to collect information on drone comb need, as she spends her days measuring the diameters of cells, in order to choose whether to lay a fertilized female or unfertilized male egg. If she integrated this information to determine the relative proportions of each type present, and then broadcast a signal, perhaps pheromonal, whose strength increased with the need for drone comb, then all builders would have access to a common and reliable source of information on comb composition. This mechanism, however, is inconsistent with the persistence of successful comb type regulation, even when the queen alone is denied access to the colony's drone comb.

How then do workers decide what type of comb to build? One possibility is that each potential builder wanders through the hive slowly accumulating information on comb composition, perhaps by directly measuring a sample of closely inspected cells, using the 
same leg-based mechanism demonstrated for queens (Koeniger, 1970). The independent assessments of bees would likely vary considerably, partly because of sampling errors and the limited cognitive abilities of individual bees, but also because a properly-regulating colony should always be near the correct ratio, so that building at least some of both comb types will be an acceptable choice. One way the bees could reach a consensus would be to use the comb itself as an information conduit. Each bee will attempt to shape the growing comb into the type of cell she has independently chosen. As she moves about the building site, however, she will encounter the growing cells created by other bees, and probably have to take into account their size in order to choose her next building step. By noting what the other bees had built, she would learn how attuned her efforts are to those of her nestmates. If, for example, she is attempting to build worker cells while the majority of her nestmates are trying to build drone cells, then her higher frequency of contacts with nascent drone cells might induce her to change her decision. In this way, a process of positive feedback, mediated by the comb, could amplify any initial difference in numbers of bees attempting each type, ultimately bringing the group to unanimity. This mechanism remains wholly speculative, but is open to both experimental test and investigation by modeling.

\section{CONCLUSIONS}

The studies reviewed here represent only the first steps in understanding the developmental biology of comb. Future studies must enlarge the scope of this work to include interdependencies between comb and other colony "organs". The optimization model of Pratt (1999), for example, did not address the myriad other investment decisions that a colony makes simultaneously with comb construction, nor did it consider the fitness consequences of the regulation of comb type. The timing and amount of investment in workers, food stores, males, and reproductive swarms are all subject to selection, and are all dependent on time, on one another, and on patterns of investment in each comb type. Thus, a full understanding of the development of comb and, more importantly, that of the colony as a whole, will require simultaneous consideration of the dynamics of all these parts, in the context of the colony's fitness.

At the proximate level, experimental analyses have begun to identify key pathways governing comb type regulation, and to suggest likely avenues for investigation of timing mechanisms. In both cases, a prominent role may emerge for encounter rates, a source of information increasingly recognized for its importance in coordinating colony behavior (Gordon and Mehdiabadi, 1999; Hart and Ratnieks, 2001; O'Donnell, 2001). Encounters with empty cells or regurgitating nestmates may cue workers to the attainment of building conditions. Likewise, relative encounter rates with drone or worker cells may inform individuals of the need for each type, and encounters with growing cells built by other bees may allow them to coordinate their work with that of their nestmates. Another promising line of research is the role of positive feedback cascades generated by signals or cues passed between nestmates. These have proven fundamental to many instances of collective decision-making and spontaneous pattern formation in social insects (Camazine, 2001), as well as in collective systems more broadly (Ball, 1999). Here, they may prove important in suddenly mobilizing a large building force at the start of construction, and in aligning the efforts of all builders toward a single comb type.

Finally, a potentially fruitful line of inquiry lies in comparative study of the comb-building strategies of temperate and tropical honey bees. For the European races considered in this review, life history is largely shaped by the challenge of surviving a long, cold winter without forage or the possibility of flight. These pressures have created a pattern of intense food hoarding and highly concentrated colony growth and reproduction in the brief favorable season (Seeley, 1985; Seeley and Visscher, 1985). Tropical races, on the other hand, face less severe seasonal stresses based largely on variation in rainfall (Hepburn and Radloff, 1998). Nectar-bearing flowers are available through most of the year (Hepburn and Radloff, 1995), and when they are not, favorable flight temperatures make migration an option for finding better foraging conditions (Hepburn et al., 1993; Hepburn and 
Radloff, 1998). High colony mobility is further encouraged by the intense predation pressure experienced in the tropics (Schneider and Blyther, 1988; Winston, 1992; Hepburn and Radloff, 1998). As a result, tropical colonies rely little on food hoarding (Winston et al., 1981; McNally and Schneider, 1992; Schneider and McNally, 1994), and swarm more frequently and over a longer period (Winston et al., 1983; Hepburn and Radloff, 1998). This contrast in life history strategies between tropical and temperate races predicts divergent optimal schedules of investment in colony structures, including drone and worker comb. Comparative study thus provides a promising opportunity to generate and test predictions about the influence of environmental context on optimal investment strategies. At the proximate level of analysis, the existence of very distinct colony-level patterns can also provide a framework to explore the adaptive flexibility of the underlying decision-making mechanisms.

\section{ACKNOWLEDGMENTS}

The writing of this review was supported by the Pew Charitable Trusts (grant 2000-002558).

Résumé - Contrôle collectif du début de construction des rayons et du type de rayons chez l'Abeille domestique (Apis mellifera). Comme tout organisme les colonies d'abeilles domestiques doivent optimiser leur investissement dans les « organes » de la colonie qui assurent les diverses fonctions. Ce processus soulève deux questions d'ordre général. Quelles sont les modèles optimum d'investissement et comment les modèles au niveau de la colonie émergent-ils des actions disparates et individuelles des nombreuses abeilles dépourvues d'un contrôleur central ? Cet article de synthèse considère ces questions pour ce qui est du début de la construction des nouveaux rayons et du choix du type de rayon à construire.

Pour un choix optimum du début de construction d'un rayon les abeilles doivent équilibrer les coûts énergétiques de la construction avec les coûts éventuels d'un manque de volume de stockage durant les miellées. Des études empiriques ont montré qu'elles le font en conditionnant le début de la construction (i) à l'atteinte d'un seuil de plénitude et (ii) à la disponibilité en nectar. Un modèle d'optimisation a suggéré que cette règle est légèrement suboptimale mais que sa simplicité et sa généralité peuvent compenser cet inconvénient. L'émergence de cette stratégie à partir des décisions individuelles des abeilles reste mal comprise, mais des expériences ont jeté le doute sur l'idée longtemps admise que la construction était déclenchée par une distension accrue du jabot des butineuses.

Les colonies régulent aussi les quantités relatives des rayons de mâles et d'ouvrières. Il s'agit d'un comportement important pour fixer à la fois la taille de leur effort de reproduction et le rapport des sexes. La quantité de rayons de mâles dans un nid est gouvernée par la rétroaction négative des rayons de mâles déjà construits. Cette rétroaction dépend des ouvrières qui ont un contact direct avec le rayon de mâles dans le nid, mais ne dépend pas du contact de la reine avec le rayon. En outre la rétroaction provient du rayon lui-même plus que du couvain présent dans ses cellules, bien que le couvain puisse augmenter l'inhibition. Ces résultats suggèrent que la régulation des rayons de mâles est un processus hautement décentralisé, émergeant des décisions prises indépendamment par des milliers d'ouvrières.

\section{Apis mellifera / construction / rayon / auto- organisation / contrôle décentralisé}

Zusammenfassung - Kollektive Kontrolle der Honigbienen (Apis mellifera) beim Zeitpunkt und Typ des Wabenbaus. Völker der Honigbienen sollten wie ein Organismus ihre Investition in ihre unterschiedlich genutzten „Volksorgane“ optimieren. Dieser Prozess wirft zwei allgemeine Fragen auf. Was sind optimale Muster für Investitionen und wie entstehen aus ungleichartigen Aktionen vieler Einzelbienen volkseigene Muster, ohne dass es einen zentralen Kontrolleur gibt? Dieser Überblick diskutiert diese Fragen in Bezug auf die Wahl des Baubeginns einer neuen Wabe und auf die Entscheidung, welcher Wabentyp gebaut wird.

Für eine optimale Wahl des Baubeginns einer Wabe müssen Bienen die Energiekosten des Wabenbaus gegen die Kosten von mangelndem Speicherplatz für Nektar während der Tracht aufrechnen. Empirische Studien haben gezeigt, dass sie bilanzieren und nur unter bestimmten Bedingungen mit dem Bau beginnen: (1) eine Schwelle von „Gefülltsein“ muss erreicht sein und (2) es muss eine Nektartracht geben. Ein Optimierungsmodell hat gezeigt, dass diese Regel leicht suboptimal ist, aber dieser Nachteil wird durch seine Einfachheit und Allgemeingültigkeit kompensiert. Welche Strategie bei den Entscheidungen von individuellen Bienen angewendet wird, ist nach wie vor nicht vollständig verstanden. Auf Grund von Versuchen gibt es aber inzwischen Zweifel an der lange bestehenden Idee, dass der Bau durch eine zunehmende Ausdehnung der Honigblase bei Arbeiterinnen im Innendienst ausgelöst wird.

Völker können auch die relative Anzahl von Drohnen- und Arbeiterinnenwaben in ihrem Nest bestimmen, eine wichtige Fähigkeit um beides, ihre 
reproduktive Leistung und das Verhältnis der Geschlechter, festzusetzen. Die Zahl der Drohnenwaben in einem Nest wird durch eine negative Rückkoppelung von schon vorhandenen Drohnenwaben gesteuert. Diese Rückkoppelung hängt von den Arbeiterinnen ab, die direkten Kontakt zu Drohnenwaben haben, nicht von den Kontakten der Königin. Außerdem entsteht die Rückkoppelung eher von der Wabe selbst als von der darin vorhandenen Brut, aber Brut kann eine Hemmung verstärken. Diese Befunde deuten darauf hin, dass die Regulierung des Baus von Drohnenwaben ein größtenteils dezentraler Prozess ist, der durch unabhängige Entscheidungen von Tausenden von Arbeiterinnen entsteht.

\section{Honigbienen / Wabenbau / Drohnen / dezentrale Kontrolle / Selbstorganisation}

\section{REFERENCES}

Ball P. (1999) The self-made tapestry: pattern formation in nature, Oxford University Press, Oxford.

Belic M.R., Skarka V., Deneubourg J.L., Lax M. (1986) Mathematical model of honeycomb construction, J. Math. Biol. 24, 437-449.

Camazine S. (2001) Self-organization in biological systems, Princeton University Press, Princeton, NJ.

Darchen R. (1968) Le travail de la cire et la construction dans la ruche, in: Chauvin R. (Ed.), Traité de biologie de l'abeille, Masson, Paris, p. 566.

Detrain C., Deneubourg J.L. (2002) Complexity of environment and parsimony of decision rules in insect societies, Biol. Bull. 202, 268-274.

Ferguson L.A., Winston M.L. (1988) The influence of wax deprivation on temporal polyethism in honey bee (Apis mellifera L.) colonies, Can. J. Zool. 66, 1997-2001.

Free J.B. (1967) The production of drone comb by honeybee colonies, J. Apic. Res. 6, 29-36.

Free J.B. (1987) Pheromones of social bees, Comstock Pub. Associates, Ithaca, NY.

Free J.B., Williams I.H. (1975) Factors determining the rearing and rejection of drones by the honeybee colony, Anim. Behav. 23, 650-675.

Freudenstein H. (1960) Einfluss der Pollennahrung auf des Bauvermögen, die Wachsdrüsen und den Fettkörper der Honigbiene (Apis mellifera L.), Zool. Jahrb. Abt. Allg. Zool. Physiol. Tiere 69, 95-124.

Goetze G., Bessling B.K. (1959) Die Wirkung verschiedener Fütterung der Honigbiene auf Wachserzeugung und Bautätigkeit, Z. Bienenforsch. 4, 202-209.
Gordon D.M., Mehdiabadi N.J. (1999) Encounter rate and task allocation in harvester ants, Behav. Ecol. Sociobiol. 45, 370-377.

Hart A.G., Ratnieks F.L.W. (2001) Why do honeybee (Apis mellifera) foragers transfer nectar to several receivers? Information improvement through multiple sampling in a biological system, Behav. Ecol. Sociobiol. 49, 244-250.

Hepburn H.R. (1986) Honeybees and wax, SpringerVerlag, Berlin.

Hepburn H.R. (1998) Reciprocal interactions between honeybees and combs in the integration of some colony functions in Apis mellifera L., Apidologie 29, 47-66.

Hepburn H.R., Magnuson P.C. (1988) Nectar storage in relation to wax secretion by honeybees, $\mathrm{J}$. Apic. Res. 27, 90-94.

Hepburn H.R., Whiffler L.A. (1991) Construction defects define pattern and method in comb building by honeybees, Apidologie 22, 381-388.

Hepburn H.R., Radloff S.E. (1995) First approximation to a phenology of the honeybees (Apis mellifera) and flora of Africa, Oecologia 101, 265-273.

Hepburn H.R., Radloff S.E. (1998) Honeybees of Africa, Springer, Berlin.

Hepburn H.R., Hugo J.J., Mitchell D., Nijland M.J.M., Scrimgeour A.G. (1984) On the energetic costs of wax production by the african honeybee, Apis mellifera adansonii, S. Afr. J. Sci. 80, $363-$ 368.

Hepburn H.R., Villet M.H., Jones G.E., Carter A.R., Simon V.I., Coetzer W. (1993) Winter absconding as a dispersal mechanism of the cape honeybee, S. Afr. J. Sci. 89, 294-297.

Huber F. (1814) Nouvelles observations sur les abeilles, Dadant, Hamilton, Illinois.

Kelley S. (1991) The regulation of comb building in honey bee colonies, Cornell University.

Koch H.G. (1961) Der Baubeginn der Bienenvölker als phänologisches Ereignis, Z. Angew. Meteorol. 4, 69-82.

Koeniger N. (1970) Factors determining the laying of drone and worker eggs by the queen honeybee, Bee World 51, 166-169.

Kolmes S.A. (1985) An ergonomic study of Apis mellifera (Hymenoptera: Apidae), J. Kans. Entomol. Soc. 58, 413-421.

Lau D. (1959) Beobachtungen und Experimente über die Entstehung der Bienenwabe (Apis mellifica L.), Zool. Beitr. 4, 233-306.

Ledoux M.N., Winston M.L., Higo H., Keeling C.I., Slessor K.N., Le Conte Y. (2001) Queen pheromonal factors influencing comb construction by simulated honey bee (Apis mellifera L.) swarms, Insectes Soc. 48, 14-20.

Lee P.C., Winston M.L. (1985) The effect of swarm size and date of issue on comb construction in newly founded colonies of honeybees (Apis mellifera L.), Can. J. Zool. 63, 524-527. 
Mangel M., Clark C.W. (1988) Dynamic modeling in behavioral ecology, Princeton University Press, Princeton, New Jersey.

McLellan A.R. (1967) Honeybee colony weight as an index of honey production and nectar flow: a critical evaluation, J. Appl. Ecol. 14, 401-408.

McNally L.C., Schneider S.S. (1992) Seasonal cycles of growth, development and movement of the African honey-bee, Apis mellifera scutellata, in Africa, Insectes Soc. 39, 167-179.

Morse R.A. (1965) The effect of light on comb construction by honeybees, J. Apic. Res. 4, 2329.

Neumann P., Hepburn H.R., Radloff S.E. (2000) Modes of worker reproduction, reproductive dominance and brood cell construction in queenless honeybee (Apis mellifera L.) colonies, Apidologie 31, 479-486.

O'Donnell S. (2001) Worker biting interactions and task performance in a swarm-founding eusocial wasp (Polybia occidentalis, Hymenoptera: Vespidae), Behav. Ecol. 12, 353-359.

Page R.E., Metcalf R.A. (1984) A population investment sex ratio for the honey bee (Apis mellifera L.), Am. Nat. 124, 680-702.

Page R.E., Fondrk M.K., Robinson G.E. (1993) Selectable components of sex allocation in colonies of the honeybee (Apis mellifera L.), Behav. Ecol. 4, 239-245.

Perrin N., Sibly R.M. (1993) Dynamic models of energy allocation and investment, Annu. Rev. Ecol. Syst. 24, 379-410.

Pratt S.C. (1998a) Condition-dependent timing of comb construction by honeybee colonies: how do workers know when to start building? Anim. Behav. 56, 603-610.

Pratt S.C. (1998b) Decentralized control of drone comb construction in honey bee colonies, Behav. Ecol. Sociobiol. 42, 193-205.

Pratt S.C. (1999) Optimal timing of comb construction by honeybee (Apis mellifera) colonies: a dynamic programming model and experimental tests, Behav. Ecol. Sociobiol. 46, 30-42.

Pratt S.C. (2000) Gravity-independent orientation of honeycomb cells, Naturwissenschaften 87, 3335.

Ribbands C.R. (1953) The behaviour and social life of honeybees, Bee Research Association, London.

Rösch G.A. (1927) Über die Bautätigkeit im Bienenvolk und das Alter der Baubienen, Z. Vergl. Physiol. 6, 265-298.

Schneider S., Blyther R. (1988) The habitat and nesting biology of the African honey bee Apis mellifera scutellata in the Okavango River delta, Botswana, Africa, Insectes Soc. 35, 167-181.

Schneider S.S., McNally L.C. (1994) Developmental patterns associated with founding and swarming in colonies of the African honey-bee race, Apis mellifera scutellata Lepeletier, Apidologie 25, 530-539.

Seeley T.D. (1978) Life history strategy of the honey bee, Apis mellifera, Oecologia 32, 109-118.

Seeley T.D. (1982) Adaptive significance of the age polyethism schedule in honeybee colonies, Behav. Ecol. Sociobiol. 11, 287-293.

Seeley T.D. (1985) Honeybee ecology, Princeton University Press, Princeton, New Jersey.

Seeley T.D. (1989) Social foraging in honey bees: how nectar foragers assess their colony's nutritional status, Behav. Ecol. Sociobiol. 24, 181-199.

Seeley T.D. (1995) The wisdom of the hive, Belknap Press of Harvard University Press, Cambridge, Massachusetts.

Seeley T.D., Morse R.A. (1976) The nest of the honey bee (Apis mellifera L.), Insectes Soc. 23, 495512.

Seeley T.D., Visscher P.K. (1985) Survival of honeybees in cold climates: the critical timing of colony growth and reproduction, Ecol. Entomol. $10,81-88$.

Taber S., Owens C.D. (1970) Colony founding and initial nest design of honey bees, Apis mellifera L., Anim. Behav. 18, 625-632.

Weiss K. (1965) Über den Zuckerverbrauch und die Beanspruchung der Bienen bei der Wachserzeugung, Z. Bienenforsch. 8, 106-124.

Whiffler L.A., Hepburn H.R. (1991) The queen in relation to wax secretion and comb building in honeybees, J. Comp. Physiol. A 169, 209-214.

Winston M.L. (1992) The biology and management of Africanized honey-bees, Annu. Rev. Entomol. 37, 173-193.

Winston M.L., Dropkin J.A., Taylor O.R. (1981) Demography and life history characteristics of two honey bee races (Apis mellifera), Oecologia 48, 407-413.

Winston M.L., Taylor O.R., Otis G.W. (1983) Some differences between temperate european and tropical African and South American honeybees, Bee World 64, 12-21.

Zera A.J., Harshman L.G. (2001) The physiology of life history trade-offs in animals, Annu. Rev. Ecol. Syst. 32, 95-126. 